Rafae Koschany

\title{
Nieznośna lekkość bytu Milana Kundery w reżyserii Philipa Kaufmana: od eseju do love story
}

\begin{abstract}
Na pohybel tym, którzy mają czelność przerabiać na nowo to, co zostało już napisane! Wbić by ich na pal i smażyć na wolnym ogniu! Wykastrować i jeszcze obciąć im uszy!
\end{abstract}

\section{Adaptacja niemożliwa}

Zacytowana w motcie kwestia Pana ze scenicznej wariacji na temat dzieła Denisa Diderota posłużyła Milanowi Kunderze jako ilustracja nieco ogólniejszej opinii, która dotyczy także filmowych adaptacji literatury. Skondensowaną wersję tej myśli wyraził pisarz w osobliwym, autorskim słowniku dołączonym do Sztuki powieści, dokładniej - znalazła się ona w haśle „Rewriting”: „Wywiady, rozmowy, cytowane wypowiedzi. Przeróbki, adaptacje filmowe, telewizyjne. Rewriting jako duch epoki" ${ }^{\prime 1}$. Natomiast szerzej Kundera komentował to w przedmowie do Kubusia $i$ jego Pana, zatytułowanej znamiennie Wprowadzenie do wariacji:

Zjawisko reader's digest wiernie odzwierciedla głębokie tendencje naszych czasów i każe mi myśleć, że któregoś dnia kultura przeszłości zostanie przerobiona i całkowicie zapomniana za parawanem rewriting. Adaptacje filmowe i teatralne wielkich powieści są niczym innym jak reader's digest sui generis.

Rzecz nie w tym, by bronić nietykalnej czystości dzieł sztuki. Oczywiście Szekspir również przerabiał utwory stworzone przez innych. Ale nie robił adaptacji; posługiwał

1 Milan Kundera, Sześćdziesiąt trzy słowa, [w:] tenże, Sztuka powieści. Esej, tłum. Marek Bieńczyk, Czytelnik, Warszawa 1998, s. 128-129 (dalej cytaty z tej książki oznaczam w tekście skrótem SP i numerem strony). 
się danym utworem, aby uczynić z niego temat dla własnej wariacji, której był suwerennym autorem. [...]

Natomiast znane przeróbki Anny Kareniny dla potrzeb teatru czy kina są adaptacjami, to znaczy redukcją. Im bardziej adaptator chce dyskretnie się schować za powieścią tym bardziej ją zdradza. Redukując ją odziera ją nie tylko z wdzięku, lecz także z sensu².

Przeróbki, adaptacje filmowe, telewizyjne... Takie ironiczne wyliczenie można potraktować jako wynik rozczarowania kulturą współczesną, zwłaszcza jej wersją popularną, głównie - mass mediami (SP, 24), których działania pisarz doświadczył wiele razy na własnej skórze, także kilka lat temu, kiedy wydrukowano artykuł oskarżający go o zadenuncjowanie kolegi w czasach studenckich ${ }^{3}$. O samym filmie Kundera również mówił niezbyt często i niezbyt pochlebnie. Oprócz tego, pisał na przykład w 1995 r., że istnieje „sztuka filmowa”, którą ceni, ale której nie przyznaje większych zasług, jeśli chodzi o rzeczywisty wpływ na kształt dzisiejszej Europy „nowa technika” (w tym film) stała się przede wszystkim „podstawowym narzędziem ogłupiania” oraz „narzędziem powszechnej niedyskrecji”/4.

Początki artystycznej biografii i publicznego życia nie zapowiadały jednak tak mocno formułowanych poglądów. Milan Kundera był przecież, jak wiadomo, absolwentem FAMU, wydziału filmowego Wyższej Szkoły Artystycznej w Pradze, gdzie potem, pod koniec lat 50., prowadził wykłady z literatury. Zapamiętała go z tego okresu Agnieszka Holland, wówczas studentka; mówiła o wtajemniczeniu intelektualnym, ale i „,silnym erotyzmie", jaki roztaczał wykładowca ${ }^{5}$. Z lat 60 . pochodzą też pierwsze ekranizacje prozy Kundery, których był nawet współscenarzystą: Nikt nie będzie się śmiał Hynka Bočana (1965) oraz Ja, smutny Bóg (1969) Antonína Kachlíka6. W roku 1965 pisarz ukończył swą powieść Zart, dla wielu do dziś najbardziej "kunderowską" i najlepszą w dorobku, ale cenzura pozwoliła ją wydać dopiero po dwóch latach. Niedługo potem, w 1969 r., przeniósł ją na ekran Jaromil Jireš.

2 Milan Kundera, Wprowadzenie do wariacji, [w:] tenże, Kubuś i jego Pan. Hołd w trzech aktach dla Denisa Diderota, tłum. Marek Bieńczyk, PIW, Warszawa 2000, s. 14.

3 Por. polskie przekłady kilku czeskich tekstów (w tym oskarżającego), które ukazały się w „Res Publice Nowej” 2008, nr 4: Adam Hradílek, Petr Třešňák, Donos Milana Kundery, tłum. Patrycja Krauze, s. 96-106; Miroslav Balaštík, Dwie historie. Kundera i wniosek z aksamitnej rewolucji, tłum. Magdalena M. Baran, s. 90-92; Samuel Abrahám, O zarzutach wobec Kundery, tłum. Magdalena M. Baran, s. 94-95.

4 Milan Kundera, To nie jest moje święto, [w:] tenże, Spotkanie, przeł. Marek Bieńczyk, PIW, Warszawa 2009, s. 137-138.

5 Por. Aleksander Kaczorowski, Życie jest w powieści, „Gazeta Wyborcza”, 8.12.1995, dodatek „Magazyn Gazety” nr 49, s. 15.

6 Por. tamże. 
I wreszcie, po długiej przerwie, jeśli chodzi o doświadczenia filmowe pisarza, w roku 1988 nastąpiła premiera amerykańskiego filmu The Unbearable Lightness of Being w reżyserii Philipa Kaufmana, będącego adaptacją powieści Nesnesitelná lehkost bytí, wydanej w 1984 r. we Francji, na język polski przetłumaczonej - jako Nieznośna lekkość bytu - przez Agnieszkę Holland (i wydanej w tym samym roku w Londynie). W przygotowaniach do filmu Kundera brał podobno udział jako konsultant na etapie scenariusza (autorstwa Jean-Claude’a Carrière'a oraz Kaufmana), a także - specjalnie na potrzeby jednej ze scen - napisał coś w rodzaju wiersza-kołysanki, który filmowy Tomasz szepcze filmowej Teresie. Nie zmienia to faktu, że ostateczny kształt dzieła pisarza rozczarował: różnice pomiędzy „literacką" wersją Carrière'a a "hollywoodzkim” kompromisem Kaufmana przeważyły o ważnej decyzji. Odtąd Kundera nie pozwolił przenosić już żadnego swojego utworu na ekran. Natomiast Agnieszka Holland odgrywa $\mathrm{w}$ tej historii istotną rolę, ponieważ zamierzała zekranizować i rozmawiała na ten temat z Kunderą - Walc pożegnalny ${ }^{7}$. Mimo że do tego nie doszło, polska reżyserka okazała się najwybitniejszą, być może, uczennicą pisarza, w wielu swych dziełach rozwijającą "tropy kunderowskie". Przekonująco pisze o tym Mariola Jankun-Dopartowa, pointując, że ze względu na odmienność indywidualnych talentów i przekonań współpraca między artystami nie mogła właściwie dojść do skutku. Po lekturze tego tekstu pojawia się jednak - w ramach czystej hipotezy - silne wrażenie, że Nieznośna lekkość bytu powinna była zrealizować właśnie autorka Aktorów prowincjonalnych.

Porównywanie książki i filmu ma w przypadku Nieznośnej lekkości bytu charakter dojmująco paradoksalny. Sama powieść była już tak wielokrotnie omawiana, że nie sposób streścić tu przeważających opinii, zdecydowanie jednak uważana jest ona za wybitną (a nawet za kamień milowy w rozwoju XX-wiecznej powieści w ogóle) lub co najmniej kultową (użycie tego mglistego kwalifikatora wydaje się w pełni uzasadnione: książkę czytają kolejne pokolenia jako w pewnym sensie „lekturę obowiązkową"). Natomiast film wywołał o wiele bardziej zróżnicowane opinie, m.in. takie, że - szczególnie dla znawców i miłośników prozy Kundery - jest on wielkim (należałoby powiedzieć właściwie: długim) nieporozumieniem.

By jednak nie poprzestać na ogólnikowych stwierdzeniach, można zaryzykować tezę, że adaptacja tej właśnie powieści niejako z góry była skazana na szereg trudności, i to z wielu powodów. Wymieniłbym dwa,

7 Por. Mariola Jankun-Dopartowa, Gorzkie kino Agnieszki Holland, słowo/obraz terytoria, Gdańsk 2000, s. 180; Sławomir Bobowski, W poszukiwaniu siebie. Twórczość filmowa Agnieszki Holland, Wyd. Uniwersytetu Wrocławskiego, Wrocław 2001, s. 44. 
moim zdaniem najważniejsze. Otóż po pierwsze, właściwie każda powieść Kundery - a na pewno Nieznośna lekkość bytu - jest jednocześnie teorią powieści Kundery. „W dziele każdego powieściopisarza tkwi skrycie wizja historii powieści, idea tego, czym powieść jest" (SP, 5) - napisał autor na jednej z kart poprzedzających Sztukę powieści. Nie ma jednak zbyt wielu pisarzy, którzy by aż tak obsesyjnie, jak Kundera, udzielali tej idei głosu. Najwięcej tu podobieństw z zależnościami teorii i praktyki Umberta Eco (i często pisarze ci są porównywani), ale o ile w Imieniu róży skupia się on na intertekstualnych i metagatunkowych grach, o tyle Kundera eksploruje problematykę narracji i kompozycji. To pisarz, który sam się interpretuje - jego poglądy na temat powieści, niejednokrotnie inkrustowane przykładami własnej twórczości, na stałe złączone zostały z tym, co wiemy o samych utworach. Pewna złośliwość podpowiada, że zachodzi tu proces podobny do oddziaływania filmowych adaptacji: w świadomości odbiorców zanika granica pomiędzy tym, co oryginalne, a tym, co należy do interpretacji. I tak, jak adaptacja jest perswazyjną, niezwykle silnie odciskającą się na wyobraźni wersją powieści, tak lektura Sztuki powieści (wraz $\mathrm{z}$ uwagami pomieszczonymi w Zdradzonych testamentach, Zasłonie i Spotkaniu) nie pozwala już czytać Żartu, Śmiesznych miłości czy Walca pożegnalnego bez narzucania odpowiedniej siatki pojęć. Zapytywanie o sens egzystencji, wariacja, polifonia - wszystkie te głosy czytelnik uruchamia w trakcie czytania kolejnych dzieł pisarza.

Po drugie, co zresztą wprost nawiązuje do poprzedniej uwagi, powieść według Kundery - od poziomu kompozycji i narracji do oceny jej roli w rozwoju kultury europejskiej - jest dyskursem równoległym do filozofii, a właściwie, jego zdaniem, od filozofii ważniejszym. W tym kontekście Nieznośna lekkość bytu z całą pewnością jest powieścią filozoficzną; już sam tytuł to pewnie jeden z najbardziej „filozoficznych" tytułów w historii powieści w ogóle. Pozostaje zatem zapytać, jak - konieczne przecież - odkształcenia, uproszczenia i skróty można zinterpretować nie krytycznie, ale z korzyścią dla omawianego procesu adaptacji. Co ostatecznie stanowi efekt translacji?

\section{Filozofia powieści}

Na samym początku trzeba zaznaczyć, że powieść Kundery jest - nawet z perspektywy czasu na nią patrząc - eksperymentalna i nowatorska. Nie wzięła się ta forma znikąd, to oczywiste; zresztą w swych esejach pi- 
sarz wielokrotnie podkreślał, jakie długi zaciągnął u Rabelais'go, Cervantesa, Diderota, Sterne'a, Tołstoja, Musila, Brocha i wielu innych. Jego propozycja jest zatem zakorzeniona $\mathrm{w}$ tradycji, ale jednocześnie przyjmuje formę nową - adekwatną do swoich czasów. Zależność tę ilustruje na przykład zastosowanie techniki zmiennych punktów widzenia (również nie nowej przecież) w Żarcie - jako odpowiednika przekonania (autora lub narratora; ich odróżnianie u Kundery to osobna kwestia) o niespójności świata i braku obiektywnych wersji rozgrywających się w nim zdarzeń. W Nieznośnej lekkości bytu zastępuje ten chwyt, i zarazem jeszcze bardziej komplikuje lekturę, mowa pozornie zależna oraz ujawnienie postaci mówiącej, scalającej narrację. Kolejny eksperyment to wprowadzenie polifonii, jednakże bardziej w rozumieniu Brocha niż Bachtina. Mianowicie, autor Śmiesznych miłości przez polifoniczność rozumie nie tyle wielogłosowość i równorzędność postaci (choć to także), ile swoistą multidyskursywność. Na płaszczyźnie powieści - na równych prawach, niezgodnie z czytelniczymi przyzwyczajeniami narracyjnymi, za to zgodnie z zasadą kontrapunktu - umieszcza różne formy wypowiedzi czy różne narracje, m.in. opowieść, filozofię i sen, czyli narrację oniryczną (SP, 69).

Powiedzieć, że film Kaufmana jest o wiele mniej eksperymentalny od powieści, to mało. Właściwie jest to dość klasyczna narracja (z małymi wyjątkami, o których dalej), w dodatku silnie osadzona w konwencji gatunkowej melodramatu. Presupozycyjny charakter mają tu zresztą ujęcia plakatowe (oraz późniejsze - na okładkach wydań DVD), czasem nieco odmienne w różnych krajach dystrybucji, jednak najczęściej powtarzające dość stereotypowo wykorzystaną ikonografię: Tomasz i Teresa jako para zakochanych, ewentualnie trójkąt, czyli z Sabiną w tle, czasem z dodatkami ważnych rekwizytów: kapelusza bądź lustra.

Takie klasyczne filmowe opowiadanie sprawia wrażenie, dość tradycyjnie rozumianej, przyliterackości. Linearność, narracyjna ciągłość, a nawet długość filmu (prawie trzy godziny) decydują o swoistej „lekturze”. Oczywiście, przyliterackość ta stoi w zasadniczej sprzeczności z nowatorstwem powieści Kundery, a przypomina raczej technikę opowiadania rodem z XIX w. (jak zresztą ciągle większość klasycznych, hollywoodzkich produkcji), jednakże w tym przypadku, gdy i tak wiele powieściowych wątków trzeba było wyeliminować, stanowi to niezaprzeczalną wartość. Czas dany widzowi na utożsamienie z fikcyjnym światem przedstawionym i jego bohaterami wydaje się znaczącym gestem twórców, trudno zresztą przypuszczać, by o tego rodzaju decyzji miały przesądzić kwestie komercyjne. 
W kontekście narracji i problemów z jej „przekładem” na osobną uwagę zasługuje też - niewykorzystany wprawdzie do końca - pomysł z początku filmu. Otóż w jego czołówce oglądamy międzyujęciowe napisy informacyjne, wprowadzające $\mathrm{w}$ historię: o Tomaszu jako młodym lekarzu w Pradze 1968 r., o Sabinie, która go najlepiej rozumiała (chodzi o erotyczne podboje bohatera) oraz o uzdrowisku, do którego pojechał, by w zastępstwie kolegi dokonać operacji. Całość (napisy jako plansze, charakterystyczna muzyka oraz „powaga” scen, a właściwie scenek) przywołuje na myśl komedie okresu niemego oraz buduje wrażenie pewnej „lekkości” narracji, odpowiadającej „lekkości” bycia Tomasza, tak chyba postrzeganego przez innych. Wprawdzie ten fragment stanowi odrębną stylistycznie etiudę, świetnie charakteryzującą głównego bohatera, ale być może szkoda, że chwyt ten nie stał się konsekwentną zasadą narracyjną i kompozycyjną. Natomiast sam ton buffo prologu zagra jeszcze w filmie kilkakrotnie, na przykład w scenie przyjazdu Teresy do Pragi i zarazem - pierwszej scenie miłosnej z Tomaszem. Kundera w esejach często pisał o komizmie "brutalnie ujawniającym błahość wszystkiego" (SP, 116), komizmie historii (któremu bardzo blisko do ironii losu), a także o komizmie seksu. W innym miejscu użył sformułowania „śmieszna miłość" - to „kategoria miłości pozbawionej powagi" (SP, 36), słabiej zaznaczona w powieściowej Nieznośnej lekkości bytu, natomiast w filmie dość wyraźna.

Wszelkiego rodzaju zabiegi narracyjne, na przykład - jak sam Kundera to określił - „przesunięcia chronologiczne” (SP, 74), zawsze służą konkretnym celom. O śmierci bohaterów nie dowiaduje się jednak czytelnik na samym początku, tak że ani argument teleologiczny (zainteresowanie skupione na przyczynach), ani emocjonalny (przyzwyczajenie czytelnika do tragicznego finału ${ }^{8}$ ) nie przydają się $w$ tym momencie. Zresztą, jak z Kunderowskich przekonań na temat rysunku losu ludzkiego wynika, śmierć bohaterów - dodatkowo poprzedzona deklaracją Tomasza o byciu szczęśliwym - była zwykłym, banalnym przypadkiem. O powieści pisze Mariola Jankun-Dopartowa: „Pozornie pozbawione większego znaczenia refleksje Teresy pasącej krowy [...] pozwalają Kunderze przejść do jednych z najgłębszych uwag o totalizacji i zniewoleniu. To z tych przyczyn nie śmierć Tomasza i Teresy (wariant kiczu melodramatycznego) zamyka powieść, ale wcześniejsza śmierć psa - rozdział Uśmiech Karenina"' ${ }^{\prime \prime}$ Roz-

8 Tak Eco wyjaśnia ogłoszenie w pierwszym zdaniu tekstu śmierci bohaterki Love Story; por. Umberto Eco, Superman w literaturze masowej. Powieść popularna: między retoryka a ideologia, tłum. Joanna Ugniewska, PIW, Warszawa 1996, s. 37.

9 Mariola Jankun-Dopartowa, dz. cyt., s. 195. 
wiązanie Kaufmana, z jednej strony, jest odmienne: o śmierci małżonków dowiaduje się Sabina, a nie syn Tomasza, którego wątek w filmie został pominięty; śmierć Karenina, mimo że mogłaby być interpretowana zgodnie z Kunderowską filozofią, iż szczęśliwe są tylko zwierzęta ${ }^{10}$, następuje wcześniej; filozoficznego monologu wewnętrznego Teresy o podporządkowaniu zwierząt człowiekowi jako metaforze totalitaryzmu z pewnością nie można było rozsądnie $\mathrm{w}$ filmie zainscenizować. Ze strony drugiej jednak, w zasadniczym, chronologicznym ujęciu wersja ta okazuje się zbieżna z powieścią. Powiedziałbym nawet, że dla czytelnika powieści Kundery stanowi niemałe zaskoczenie - wyprzedzenie finału, co prawda, potwierdza melodramatyczną konwencję, ale jednocześnie uderza $\mathrm{w}$ tak długo żywioną przez widza nadzieję na szczęśliwe zakończenie. Ta niejednoznaczność gatunkowa nie bezpośrednio, ale dość sugestywnie przystaje do Kunderowskiej wizji świata, pełnej absurdów i antynomii.

Wszystkie konieczne ograniczenia, jakie stoją przed adaptatorem powieści na wskroś zeseizowanej, rezygnującego w swej propozycji z analogicznej próby polifonicznego łączenia różnych dyskursów, doprowadzają w ostateczności do zaakcentowania linearnego przebiegu zdarzeń. Filmowa Nieznośna lekkość bytu to love story - z historią w tle, co ma dla książki, ale także dla filmu, istotne znaczenie. Jest zatem miłość (dość skomplikowana, bo mowa o podstawowym trójkącie miłosnym bohaterów, nie licząc „czwartego" Franza, wielu miłostek Tomasza oraz spotkania Teresy z inżynierem) oraz uwikłanie człowieka w historię: decyzja o takim sposobie transpozycji, być może słuszna, sprawia, że film - by wydobyć w tym miejscu jego główny temat - staje się opowieścią o zdradzie. W najbardziej podstawowym wymiarze jest on historią kolejnych zdrad (eliminacja "filozofującej" narracji doprowadziła do zagęszczenia zdarzeń, a te właśnie taki charakter mają), które warunkują i ciąg dalszy losów postaci, i ich tożsamość (czy „nietożsamość” w przypadku Teresy). Ta uwaga nie dotyczy li tylko Tomasza, chociaż z pewnością to przede wszystkim on może być postrzegany jako osoba zdradzająca. Widzimy go nawet z książką o przygodach Casanovy w Szwajcarii. Właściwie do samego końca Tomasz jest tak przedstawiany: wystarczy sama obecność, jedno jego spojrzenie, by - już erotycznie - odwzajemniała je kobieta. Z kolei wątek zdrady rozumianej politycznie zostaje wyjaśniony przez pryzmat mitu o Edypie, zinterpretowanego przez Tomasza jako przykład świadomości zbrodni stalinizmu,

10 Por. Joanna Gromek, Szczęście psa, [w:] Kundera. Materiały z sympozjum zorganizowanego w Katowicach w dniach 25-26 kwietnia 1986 r., red. Jerzy Illg, Polonia, Londyn 1988. 
za którą zdradzający, w tym miejscu lepiej powiedzieć - zdrajcy, sami powinni się ukarać. Ten wątek powieściowy został w filmie wyjątkowo konsekwentnie poprowadzony, bo odtworzona została i historia artykułu napisanego przez Tomasza (oraz konsekwencje odmowy napisania „,sprostowania"), i rozmowa z przyjaciółmi na ten temat (na zabawie tanecznej), i wreszcie książka (Król Edyp Sofoklesa) oglądana przez Teresę w mieszkaniu inżyniera, z którym postanawia zdradzić Tomasza (trochę mu na złość, trochę w zemście, ale przede wszystkim - jakby w zgodzie ze swoim dążeniem do upadku).

\section{Powieść filozoficzna}

„Filozofia powieści” - tak jak Kundera rozumie gatunek, jego historię oraz wpływ na kulturę europejską i tożsamość człowieka - bardzo często, jak już wspomniałem, przenoszona była na filozoficzne interpretacje samych utworów literackich autora Żartu. Powieści te inspirowały również wybitnych myślicieli, by wymienić chociażby Richarda Rorty'ego ${ }^{11}$, Stefana Morawskiego ${ }^{12}$ czy Zygmunta Baumana ${ }^{13}$. Tym razem warto zadać pytanie, na ile filozofię Kundery z Nieznośnej lekkości bytu udało się przetransponować do dzieła filmowego. Zarówno po stronie twórców, jak i przyszłych interpretatorów filmu, pisarza i, może przede wszystkim, miłośników jego prozy oraz tej właśnie powieści - istotna jest ta sama troska o sensy zagubione w przekładzie. I ze względu na specyficzną formę Nieznośnej lekkości bytu - achronologiczną, zeseizowaną, polifoniczną, z narratorem, który mówi o sobie "ja”, wszystko wie i układa zdarzenia jak puzzle - właściwie staje się swoistym założeniem, że proporcje „zagubionego" i „odnalezionego" nie będą równomierne.

Niektóre z filozoficznych wątków powieściowych zasugerowano, co prawda, w filmie, ale dla tych, którzy nie czytali tekstu, nie mają one większego znaczenia. Brzmią wręcz sztucznie, na przykład kierowana do Tomasza wypowiedź Sabiny o kiczu. Z kolei czytelnik pierwowzoru usilnie będzie filmowych oddźwięków refleksji Kundery o kiczu szukał - i nie

11 Richard Rorty, Heidegger, Kundera, Dickens, tłum. Marek Kwiek, [w:] Między pragmatyzmem a postmodernizmem, red. Andrzej Szahaj, Wyd. UMK, Torun 1995.

12 Stefan Morawski, Wyciag z Kundery i kilka o jego dziele domysłów, "Sztuka i Filozofia” 1996, nr 12.

13 Zygmunt Bauman, O związu morganatycznym teorii z literatura myśli (roztrzepanych) parę, „Teksty Drugie” 2010, nr 1-2; tenże, Prawda nauki, prawda sztuki, [w:] tenże, Ponowoczesność jako źródło cierpień, Wyd. Sic!, Warszawa 2000. 
w tym rzecz, by teraz to czynić. Otóż wydaje się, że tak jak Kaufman konsekwentnie opowiada o zdradzie, czyniąc ją głównym tematem filmu, tak na poziomie wykładni filozoficznej próbuje - na ile udanie? - oddać tytułową „lekkość bytu”, rozumianą jako przypadkowość, ironiczność (ironia losu i ironia historii), szkicowość. W powieści rola przypadku jest pierwszorzędna i wyraźnie podkreślona w narracji, ale w filmie umyka - nie tyle nawet przez celowe i konieczne elipsy, ile ze względu na charakter samego filmowego opowiadania, to znaczy bez wyraźnego głosu narratora (nikt tu wprost nie tłumaczy metafizycznych założeń opowieści - że Teresę i Tomasza połączyła sieć przypadków). Ale jednocześnie film, wprowadzający w opowiadaną historię in medias res, jest przecież medium "z natury" przypadkogennym i to, co opowiedziane, może pokazać. Klamrowe zestawienie pokoju nr 6, w którym nocuje Tomasz w sanatorium, gdy poznaje Teresę, i pokój nr 6 (rzecz dopisana w filmie), w którym jako małżonkowie zatrzymują się po spontanicznie zorganizowanej potańcówce, prowadzi do podobnej - dotyczącej sieci przypadków - konkluzji.

Zbliżona do powieściowej jest również charakterystyka postaci, ich decyzji i konsekwencji z nich wynikających. To jeden z głównych tematów Kundery: oscylacja pomiędzy zamiarami a czynami, wolnym wyborem a jakąś zewnętrzną siłą, przypadkiem a ciężarem istnienia. Los bohaterów Nieznośnej lekkości bytu konstytuowany jest przez przypadki i kontekst społeczno-polityczny; los przychodzi z zewnątrz, tylko wywołuje różne reakcje w Tomaszu, Teresie, Sabinie i Franzu. Na przykład filmowy Tomasz zaraz na początku filmu w rozmowie z Sabiną żałuje, że nie może „przepisać” życia dwa razy (tak jakby możliwe były jego dwa scenariusze $)^{14}$, że życie jest lekkie, jak szkic. I właściwie tak postępuje: od zdarzenia do zdarzenia, które najczęściej mają erotyczny charakter. Pominięcie przez scenarzystów informacji o synu to nie tylko zwykła redukcja, ale także informacja dodatkowa: Tomasz jest tym lżejszy, tym bardziej niezakorzeniony, bez wiążącej przeszłości, ale też bez przyszłości. Kundera, krytycznie wypowiadając się o filmowych adaptacjach powieści, pisze o Tołstoju:

[...] w sposób radykalnie nowy w dziejach powieści postawił on pytanie o ludzkie czyny; odkrył, jak fatalnie ważą nad podejmowaną decyzją przyczyny nieuchwytne dla rozumu. Dlaczego Anna popełniła samobójstwo? Tołstoj posunie się aż do użycia Joyce'owskiego niemal monologu wewnętrznego, aby ukazać tkankę irracjonalnych

14 Por. Milan Kundera, Nieznośna lekkość bytu, tłum. Agnieszka Holland, PIW, Warszawa 2004, s. 9 i 168-169. 
motywów, które zdalnie sterowały jego bohaterką. Otóż każda adaptacja tej powieści usiłuje, co leży w samej naturze reader's digest, uczynić jasnymi i logicznymi przyczyny postępowania Anny, usiłuje je zracjonalizować; adaptacja staje się w ten sposób bezwzględnym zaprzeczeniem oryginalności powieści ${ }^{15}$.

Zrozumiałe jest, że forma specyficznej narracji z Nieznośnej lekkości bytu, a także postać samego narratora, komentującego przebieg zdarzeń i filozofującego na przeróżne tematy, od kategorii „lekkości” i "ciężaru”, przez „kicz”, do "gówna”, nie mogły być w filmie odtworzone. Także postaci u Kundery nie są bytami autonomicznymi, ale mają charakter dyskursywny - los każdej z nich mówi coś istotnego o losie w ogóle ${ }^{16}$. Postacie te „rodzą się" ze zdań lub zdarzeń. Czytamy o tym na początku drugiego rozdziału: Byłoby głupie, gdyby autor starał się wmówić czytelnikowi, że jego postacie istniały naprawdę. Nie zrodzity się one z ciała matki, ale z jednego czy dwóch sugestywnych zdań lub z jakiejś elementarnej sytuacji. Tomasz narodzit się ze zdania: "Einmal ist keinmal”. Teresa narodzita się z burczenia w brzuchu ${ }^{17}$. Stąd Tomasz obsesyjnie będzie traktował „lekkość”, szkicowość życia, którego nie można powtórzyć, dla Teresy zaś konstytutywny będzie konflikt między duszą a ciałem. A zatem, z jednej strony, narracyjne rozważania o losie bohaterów, na przykład o podejmowaniu przez nich decyzji, w filmie przestają mieć znaczenie. Nie dowiadujemy się więc, dlaczego coś postanawiają, o czymś decydują, ale taka właśnie irracjonalność postępowania, z drugiej strony, jest przecież tematem książki oraz autorefleksyjnych esejów pisarza. Można powiedzieć nawet, że brak jakiejkolwiek instancji zewnętrznej dla zachowania postaci (przede wszystkim nadrzędnej narracji), zachowania często absurdalnego czy niezrozumiałego, sprawia, że ta ich cecha - komentowana często jako widoczny brak umotywowania psychologicznego - tym bardziej przekonuje.

W swych wcześniejszych powieściach Kundera przepracowywał kolejne pojęcia, ważne dla protagonistów i konstytuujące ich byt, ale też pojmowane jako swoiste klucze interpretacyjne czy wręcz kompozycyjne chwyty. Umieszczony w Nieznośnej lekkości bytu "Mały słownik niezrozumianych słów", element niby heterogeniczny, ale w myśl gatunkowej polifonii niezbędny w całości utworu, świadczy o ambicjach pisarza-filozofa. Oczywista rezygnacja w filmie z pojęć (jakiegoś filmowego ekwi-

\footnotetext{
15 Milan Kundera, Wprowadzenie do wariacji..., s. 14; por. także SP, 14-15.

16 Por. Ewa Graczyk, Człowiek Kundery, [w:] Kundera. Materiały z sympozjum..., s. 81-82.

17 Milan Kundera, Nieznośna lekkość bytu..., s. 31.
} 
walentu „słownika niezrozumianych słów”), w ramach przekodowania z opowiadania na pokazywanie, prowadzi do zaakcentowania znaczących przedmiotów. Wymienić tu trzeba przede wszystkim "rekwizyty” Sabiny: kapelusz i - zwłaszcza - lustro, nie aż tak mocno wyeksponowane $\mathrm{w}$ powieści ${ }^{18}$. W scenach miłosnych $\mathrm{z}$ Tomaszem najpierw jest ono duże, owalne, ze stylową ramą, potem - w znaczącej scenie zmiany warty, kiedy Sabina właściwie zdradza Franza z Tomaszem, pojawia się lustro popękane (praca plastyczna bohaterki).

Tak jak dla Sabiny lustro, tak dla Teresy aparat fotograficzny są pewnymi atrybutami. Może zbytnim uproszczeniem byłoby stwierdzenie, że Sabina przygląda się sobie, a Teresa innym. Chodziłoby raczej o inne porównanie: Sabina jest siebie w pełni świadoma (przede wszystkim świadoma swej niezależności i - związanej z tym - ciągłej konieczności zmiany), natomiast Teresa to kobieta szukająca tożsamości, słaba (jak sama to w filmie określa, gdy wraca z Genewy do Pragi, do kraju ludzi podobnych do niej).

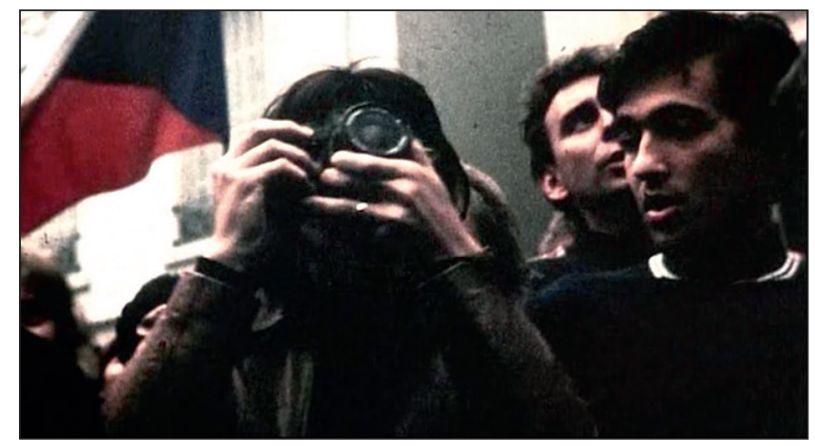

Fot. 6. Nieznośna lekkość bytu (1978, reż. Philip Kaufman) Atrybutem Teresy jest aparat fotograficzny

Obie postaci podejmują pochopne, irracjonalne czasem decyzje, jednak podczas gdy Sabina robi to zgodnie ze swoim poczuciem wolności, Teresą rządzi rozpacz. Żywiołem podstawowym będzie dla niej woda dopisane $\mathrm{w}$ filmie sceny $\mathrm{w}$ basenie (rzeczywiste bądź wyobrażone) również symbolicznie pokazują niedoświadczenie, niepewność, „płynność”

18 Na okładkach książek z kolei zdecydowanie króluje melonik, często zawieszony w powietrzu - jako znaczący rekwizyt z życia erotycznego Sabiny (i Tomasza) oraz - z pewnością - uchwytny, niemalże ilustracyjny symbol tytułowej „lekkości”. 
charakteru Teresy, jej ciągłe zapytywanie o tożsamość ${ }^{19}$. Tak nakreśloną różnicę świetnie oddają też aktorki (dojrzała Lena Olin i dziewczęca Juliette Binoche $)^{20}$.

\section{Nieszczęśliwe zakończenie?}

Oczywiście, mówiąc o filmie Kaufmana w kontekście filozofii powieści (według Kundery) oraz powieści filozoficznej (czyli Nieznośnej lekkości bytu), narzuca się pytanie, czy adaptacja taka jest w ogóle możliwa? Odpowiedź skierowałbym w inną stronę: Nieznośna lekkość bytu to adaptacja wielokrotna. Najpierw - z książki na film. Potem - z kultury na kulturę; nie bez znaczenia pozostaje przecież fakt, że powstał film amerykański, z zakładanym również amerykańskim i międzynarodowym widzem. Na tym poziomie należy też wspomnieć o wyborze języka angielskiego, ale nie to było najgorszą decyzją. Otóż po angielsku (to znaczy sztuczną, sztywną angielszczyzną) mówią także nieanglojęzyczni aktorzy, czego w żaden sposób nie da się uzasadnić fabularnie (pomijam już dodatkowe niekonsekwencje, na przykład mężczyźni w sanatoryjnym basenie mówią po czesku). I wreszcie, wracając do wielowarstwowej adaptacji tekstu Kundery - jest to także próba przekładu tekstu na wskroś filozoficznego. Jak wiadomo, teoretycznie rzecz biorąc, różnica ,języka” nie stanowi przeszkody w dokonaniu adaptacji, jednak spotkanie aż trzech rodzajów translacji - intersemiotycznej, interkulturowej oraz interdyskursywnej staje się nie lada wyzwaniem. Może i tę książkę należałoby dopisać do listy Kundery: „W literaturze światowej istnieją dwie powieści całkowicie nieredukowalne, zupełnie unrewritable, nie do przerobienia: Tristram Shandy i Kubuś Fatalista”. ,JJakże uprościć - pytał - ich cudowny nieporządek, żeby coś z niego zostało? I co by miało z niego zostać?"21.

Inna kwestia wiąże się z rolą mediów (medium powieści i medium filmu) w kulturze. Według Kundery - przypominał o tym Rorty - powieść jest synonimem „utopii demokratycznej”; „[...] my, mieszkańcy Za-

19 Pierwotnie Nieznośna lekkość bytu miała mieć tytuł Planeta niedoświadczenia (por. SP, 122).

20 Od narratora powieści możemy się dowiedzieć, że „Teresa i Sabina stanowiły dwa bieguny jego [Tomasza] życia, bieguny odległe, nie do pogodzenia, lecz piękne" (Milan Kundera, Nieznośna lekkość bytu..., s. 24).

21 Milan Kundera, Wprowadzenie do wariacji..., s. 15. 
chodu - pisał dalej - zawdzięczamy tę świadomość i tę wrażliwość [na różnorodność - przyp. R. K.] powieściopisarzom, a nie filozofom lub poetom" ${ }^{\prime 22}$. Nie można też pomijać faktu, że Kunderze, w masowym niemal wymiarze i zgodnie z jego poglądami na ten temat, udało się przemycić tekst filozoficzny pod postacią powieści. Patrząc na to $z$ odmiennej perspektywy: otóż filmoznawczy dyskurs pierwszych dekad XX w., kiedy ruchome obrazy zaczynały pretendować do roli sztuki, często zatrzymywał się na skojarzeniu filmu jako kontynuatora powieści - nie tylko w sensie formalnym, ale również w znaczeniu roli społecznej. Tak jak odpowiadały sobie XIX-wieczna powieść i wzrastające wówczas miasto, tak film o wiele lepiej odpowiada przemianom XX w. Film w znacznym stopniu zastąpił (zasłonił!) powieść, a jej rola, tak często przez Kunderę analizowana, również bywa przez film - tę kolejną „demokratyczną utopię" - podmieniana, ciągle wypierając, rzecz jasna, filozofię i poezję. A na ironię losu zakrawa już fakt, że technika kompozycji Kundery, jego wielkie osiągnięcie pisarsko-muzyczne, bywa kojarzona z montażem filmowym ${ }^{23}$.

Na zakończenie powracam do motta, przytaczam je jeszcze raz, łącznie z szerszym kontekstem i innymi jeszcze problemami, o których nie wspominałem na początku:

PAN: [...] Czy znasz tego, kto pozwolił sobie na nowo nas napisać?

KUBUŚ: To dureń, proszę pana. Ale teraz, skoro już zostaliśmy na nowo napisani, nic się już nie da zrobić.

PAN: Na pohybel tym, którzy mają czelność przerabiać na nowo to, co zostało już napisane! Wbić by ich na pal i smażyć na wolnym ogniu! Wykastrować i jeszcze obciąć im uszy! [...]

KUBUŚ: Proszę pana, ci, którzy przerabiają na nowo, nigdy nie smażą się w ogniu i wszyscy im wierzą.

PAN: Myślisz, że uwierzą temu, kto przerobił naszą historię? Że nie będą sprawdzać w „tekście”, kim jesteśmy naprawdę?

KUBUŚ: Proszę pana, przerobiono nie tylko naszą historię, lecz wiele innych rzeczy. Wszystko, co zdarzyło się na tym padole, zostało już przerobione setki razy i nikomu do głowy nie przyszło sprawdzać, co wydarzyło się w rzeczywistości. Dzieje ludzkie pisane są na nowo tak często, że ludzie nie wiedzą już, kim są ${ }^{24}$.

22 Richard Rorty, dz. cyt., s. 91 i 99.

23 Por. Roman Zimand, Ten cholerny Kundera, "Almanach Humanistyczny” 1984, nr 1-2, s. 175.

24 Milan Kundera, Kubuś i jego Pan..., s. 68. 
Właściwie wszystkie te obawy, całą krytykę dotyczącą adaptacji można by przyłożyć do filmu Kaufmana. Najpierw: kto ma prawo do adaptacji? Potem, niezależnie od efektu: każda adaptacja jest swego rodzaju występkiem. Wreszcie: adaptacja - w epoce rewritingu i jako narzędzie „ogłupiania” oraz „powszechnej niedyskrecji” - skutecznie zasłania oryginał. Kundera, odrzucając film, mógł rzeczywiście poczuć, że jego poglądy widoczne są tu jak na dłoni. Tymczasem wydaje się, że filmowa Nieznośna lekkość bytu nie musi podlegać takiej bezwzględnej krytyce, ponieważ ciągle można zaglądać za zasłonę i w interpretacji szukać „kunderowskich tropów". Pisanie o filmie przez pryzmat Kundery, który tak chętnie samego siebie interpretował, jest chyba i nieuniknione, i w pełni uzasadnione. 